\title{
AUTOLOGOUS FAT AUGMENTATION IN THE TREATMENT OF UNILATERAL VOCAL FOLD PARALYSIS - A 15-YEAR EXPERIENCE IN A SINGLE INSTITUTION
}

\author{
Ratko Prstačići, ${ }^{1,4}$ Juraj Slipac ${ }^{1}$, Tamara Živković Ivanović ${ }^{1}$, Ivana Šimić1, \\ Ema Babić ${ }^{1}$ and Ana Đanić Hadžibegović $c^{1,2,3}$ \\ ${ }^{1}$ ENT Department, University Hospital Centre Zagreb, Zagreb, Croatia, \\ ${ }^{2}$ Faculty of Dental Medicine and Health, Josip Juraj Strossmayer University of Osijek, Croatia, \\ ${ }^{3}$ School of Medicine, Zagreb University, Croatia, \\ ${ }^{4}$ Faculty of Education and Rehabilitation Sciences, Zagreb University, Croatia
}

\begin{abstract}
SUMMARY - Autologous fat vocal fold augmentation is a widespread surgical procedure that aims to repair glottal incompetence in patients with unilateral vocal fold paralysis (UVFP). However, there are some concerns in the literature about the long-term results of this technique. At the ENT Department of the Zagreb University Hospital Centre, this technique has been in use for more than 15 years, and a retrospective medical chart review was conducted from June 2005 to November 2019. Overall, 78 patients with UVFP met the inclusion criteria for enrolment in the study. All patients underwent at least one preoperative and two postoperative voice assessments, one early (within 3 months from surgery) and one late (at least 1 year after surgery). All tested voice outcome parameters (maximum phonation time (MPT), jitter, shimmer, noise-to-harmonic ratio (NHR)) significantly improved after surgery, both early and late postoperatively $(\mathrm{p}<0.001)$. The reoperation rate was only $10.3 \%(8 / 78)$, with the majority of patients in our series experiencing long-term benefits from this surgical procedure. According to the results of our study, autologous fat vocal fold augmentation appears to be a highly useful and effective surgical technique with long-lasting results in the majority of patients suffering from UVFP.
\end{abstract}

Key words: autologous fat, augmentation, vocal fold paralysis

\section{Introduction}

The use of autologous fat is a recognized method for vocal fold augmentation in patients with unilateral vocal fold paralysis (UVFP). In the early nineties, Mikaelian ${ }^{1}$ was the first to report a successful vocal fold augmentation with autologous fat in three patients diagnosed with UVFP. Subsequently, many authors have proved the efficacy of this method, and it has also gained popularity due to its simplicity and very low complication rate ${ }^{2-7}$. That is the reason autol-

Corresponding author: Ana Đanić Hadžibegović, $M D, P h D$, ENT Department, Zagreb University Hospital Centre, Kišpatićeva 12, 10000 Zagreb, Croatia

E-mail: ana_djanic@yahoo.com ogous fat augmentation is still the golden standard in the surgical treatment of UVFP at the ENT Department of the Zagreb University Hospital Centre despite the abundance of available surgical procedures for glottal competence improvement, such as medialization thyroplasty with or without arytenoid adduction, injection laryngoplasty using synthetic materials, or laryngeal reinnervation techniques ${ }^{8}$.

This procedure was introduced at our Department in 2005 and has to date been used to treat 96 patients with UVFP who had not responded well to conservative speech therapy.

The aim of this study was to determine the longterm results of this technique, including its safety profile and complication rate. 


\section{Methods}

A retrospective medical chart review conducted from June 2005 to November 2019 found 96 patients who had been treated endoscopically by augmentation with autologous fat into the immobile vocal fold. Based on previously-defined inclusion and exclusion criteria, 18 patients were excluded from the study, so the total number of patients enrolled in the study was 78 .

The inclusion criteria for enrolment in the study were a preoperative diagnosis of UVFP with normal mobility of the opposite vocal fold, both confirmed by fiberendoscopy. All patients underwent at least one preoperative and two postoperative voice assessments, one early (within 3 months from surgery) and one late (at least 1 year after surgery). The voice assessment included voice self-assessment, aerodynamic assessment of phonation, and acoustic analysis. Relevant parameters that were analysed were maximum phonation time (MPT), jitter, shimmer and noise-to-harmonic ratio (NHR). According to the literature, these are the most important voice outcome indicators for UVFP surgical procedures ${ }^{9}$. Acoustic analysis parameters were calculated using the Multi-Dimensional Voice Program (MDVP, Model 4500, Kay Elemetrics, USA).

Exclusion criteria from the study were reduced mobility of the opposite vocal fold confirmed by fiberendoscopy and a lack of preoperative or postoperative voice assessment data in the patient's medical records, based on a predefined protocol.

\section{Statistical analysis}

The Kolmogorov-Smirnov test was used to determine whether the examined variables were normally distributed.

Normally distributed data were represented by arithmetic mean and standard deviation with a $95 \%$ confidence interval, while data that were not normally distributed were represented by median and interquartile range. The differences in parameter values measured preoperatively, early, and late postoperatively were tested by repeated measure analysis of variance or by the Friedman test, depending on the normality of data distribution. The level of statistical significance was set at $\mathrm{p}<0.05$. Statistical analysis was performed using the Statistica 7.0 software (StatSoft, Tulsa, USA).

\section{Surgical technique}

The patients were intubated with a 5.0-diameter endotracheal tube introduced under general anesthesia. Only in a few cases of burly or considerably obese patients, a 5.5- or 6.0-diameter tube was used.Autologous fat was harvested from the lower abdomen through a small horizontal skin incision placed in the subumbilical area. Bigger pieces of fat were cut into smaller particles with a diameter of 2-3 $\mathrm{mm}$, and all fibrous and connective tissue was precisely removed from the specimen at the same time. The small fat grafts were then purified using the technique described by Niechajev $^{10}$ in order to separate the fat particles from blood, cellular debris, and free fatty acids. Such purified fat was placed into $1 \mathrm{cc}$ insulin syringes and was ready for augmentation. A laryngoscope was used to place the ventricular folds laterally to maximally expose the superior surface of the vocal folds. Under microscope control, the autologous fat was injected into the paralyzed thyroarytenoid muscle using an applicator with a special gear mechanism (Karl Storz SE \& Co.). A single point of injection was used, and the ideal puncture point was laterally and slightly anteriorly from the tip of the vocal process of the ipsilateral arytenoid cartilage. The depth of needle penetration was $5-7 \mathrm{~mm}$. Due to the anticipated resorption process, it was necessary to perform an overcorrection of approximately $30 \%$ given that the convex bulging of the augmented vocal fold must be evident at the end of the procedure. However, as the amount of overcorrection is almost impossible to measure objectively, it was left to the judgement and personal experience of the surgeon. Steroids or antibiotics were not routinely used postoperatively and voice rest was recommended for 5-7 days.

\section{Results}

The total number of patients who met the criteria for enrolment in the study was 78, out of which 56 were women $(71.8 \%)$ and 22 were men $(28.2 \%)$. The mean age of patients was 52.5 years (range 19-77). The left vocal fold was affected in 59 patients $(75.6 \%)$ and the right vocal fold was affected in 19 (24.4\%), producing an approximate ratio of $3: 1$. The most common cause of paralysis (Figure 1) was neck surgery (predominantly thyroid surgery) in 47 patients (60.3\%), followed by paralysis of unknown etiology $(n=15$; 


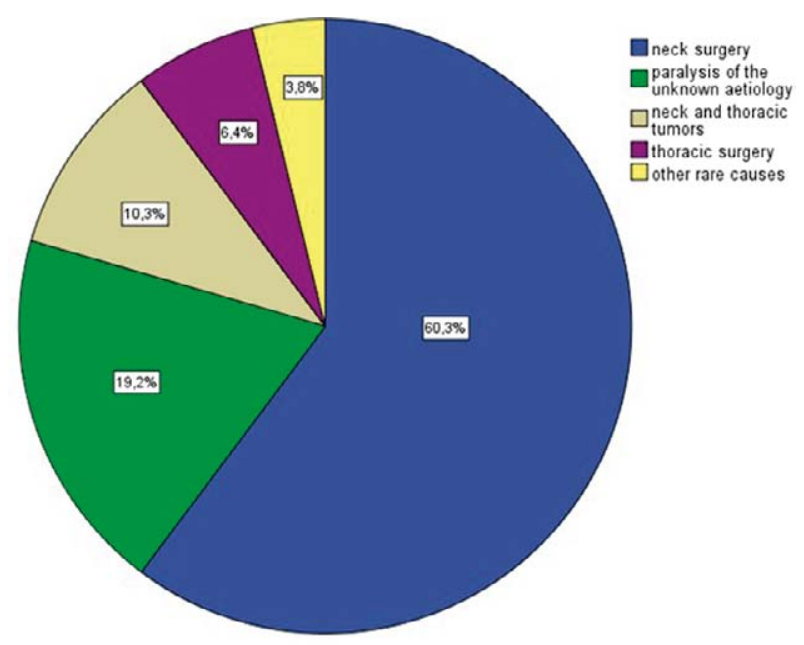

Figure 1. Etiology of vocal fold paralysis.
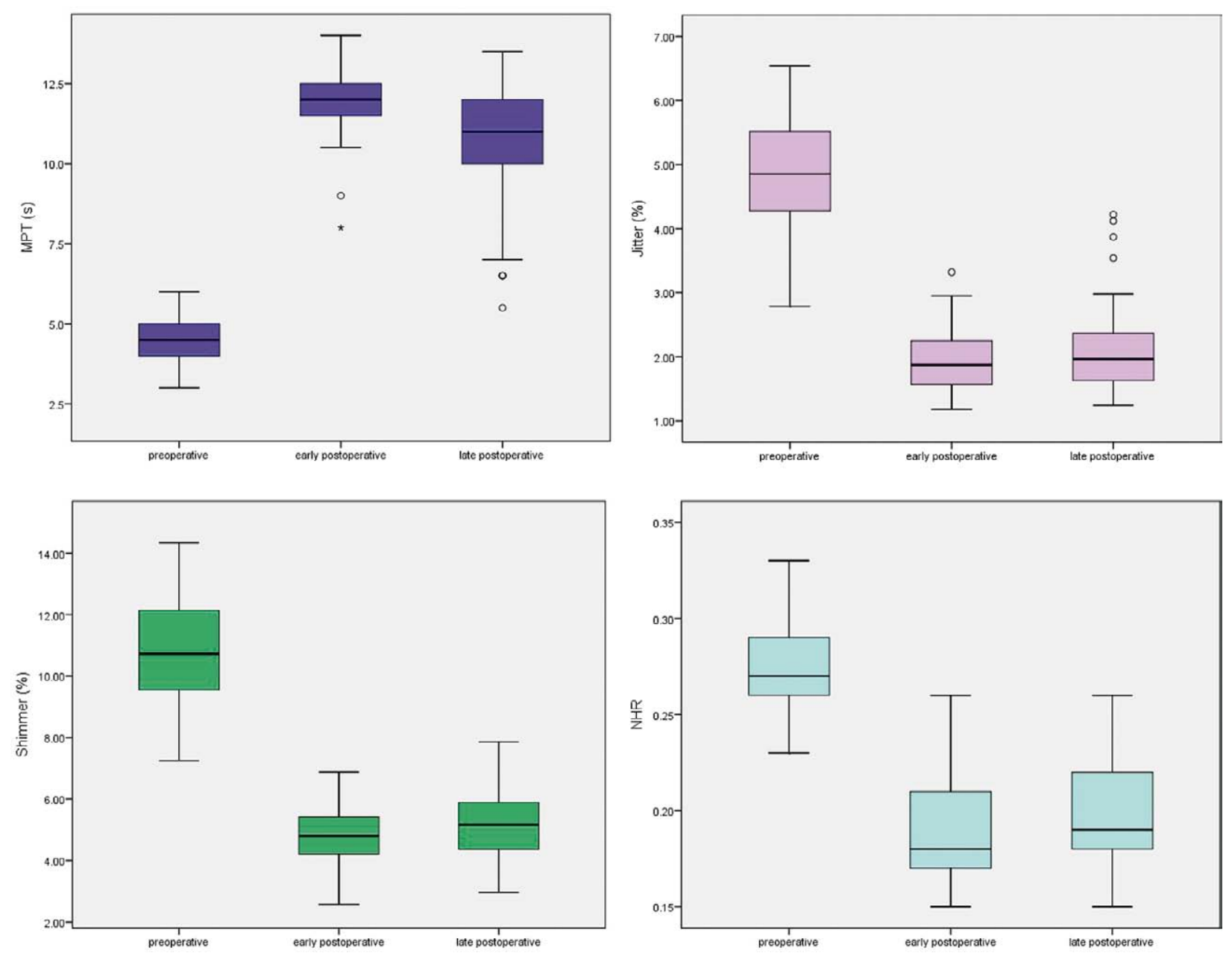

Table 1. Descriptive view of tested sample

\begin{tabular}{|l|l|}
\hline $\begin{array}{l}\text { Age } \\
\text { Mean } \\
\text { Extreme }\end{array}$ & 52.5 years \\
$19-77$ years
\end{tabular}

Figure 2. Preoperative and postoperative results of voice assessment parameters. 
Table 2. Preoperative and postoperative results of voice assessment parameters

\begin{tabular}{|c|c|c|}
\hline $\operatorname{MPT}(\mathrm{s})^{*}$ & & \\
\hline $\begin{array}{l}\text { preoperative } \\
\text { early } \\
\text { postoperative } \\
\text { late } \\
\text { postoperative }\end{array}$ & $\begin{array}{l}4.5(4-5) \\
12.3(11.5-12.5) \\
11.2(10-12)\end{array}$ & $\mathrm{p}<0.001$ \\
\hline Jitter $(\%)^{* *}$ & & \\
\hline preoperative & $4.84 \pm 0.87(4.64-5.04)$ & \\
\hline $\begin{array}{l}\text { early } \\
\text { postoperative }\end{array}$ & $1.91 \pm 0.43(1.81-2.01)$ & $\mathrm{p}<0.001$ \\
\hline $\begin{array}{l}\text { late } \\
\text { postoperative }\end{array}$ & $2.07 \pm 0.63(1.92-2.21)$ & \\
\hline Shimmer (\%)** & & \\
\hline preoperative & $10.78 \pm 1.72(10.39-11.17)$ & \\
\hline $\begin{array}{l}\text { early } \\
\text { postoperative }\end{array}$ & $4.75 \pm 0.91(4.54-4.96)$ & $\mathrm{p}<0.001$ \\
\hline $\begin{array}{l}\text { late } \\
\text { postoperative }\end{array}$ & $5.16 \pm 1.05(4.92-5.40)$ & \\
\hline $\mathrm{NHR}^{*}$ & & \\
\hline preoperative & $0.27(0.26-0.29)$ & \\
\hline $\begin{array}{l}\text { early } \\
\text { postoperative }\end{array}$ & $0.18(0.17-0.21)$ & $\mathrm{p}<0.001$ \\
\hline $\begin{array}{l}\text { late } \\
\text { postoperative }\end{array}$ & $0.19(0.18-0.22)$ & \\
\hline
\end{tabular}

* median (IQR); * mean \pm SD (CI 95\%)

19.2\%), neck and thoracic tumors $(\mathrm{n}=8 ; 10.3 \%)$, thoracic surgery $(n=5 ; 6.4 \%)$, and other rare causes $(n=3$; $3.8 \%)$.

Five patients experienced complications, 3 at the injection site and 2 at the donor site, so the overall complication rate was $6.4 \%$. At the injection site, $2 \mathrm{pa}^{-}$ tients experienced early fat extrusion and one patient developed considerable stridor and required reintubation just a few hours after the procedure. After a conservative treatment with corticosteroids and antibiotics, the patient was successfully extubated 5 days later. At the donor site, we found one case of postoperative hematoma and one case of wound infection. A reoperation procedure was necessary in 8 patients $(10.3 \%)$ : in 2 cases during the early postoperative period (patients with fat extrusion) and in the remaining cases in the late postoperative period due to a gradual but significant deterioration of voice quality.
The preoperative, early postoperative and late postoperative values of objective voice parameters are presented in Table 2 and Figure 2. All tested parameters (MPT, jitter, shimmer, NHR) significantly improved after surgery $(\mathrm{p}<0.001)$. The improved values slightly diminished in the late postoperative period, but there was still a statistically significant difference in comparison with the preoperative results $(\mathrm{p}<0.001)$.

\section{Discussion}

UVFP is an unpleasant complication primarily associated with thyroid surgery, although it may occur in many other surgical procedures, such as neck dissection, esophageal surgery, and cardiothoracic surgery. In some patients, UVFP may develop as a consequence of tumor growth, while in others the cause of paralysis may remain unknown despite extensive diagnostic work-up. The main cause of UVFP in our series was neck surgery (predominantly thyroid surgery), followed by paralysis of unknown etiology, neck and thoracic tumors, and thoracic surgery. A similar order in the etiology of paralysis can be found in the majority of recently published papers ${ }^{11,12}$. However, malignancies were cited as the most common cause of paralysis in articles dating twenty or more years ago ${ }^{13,14}$. This obvious shift in etiological trends may be explained by an increase in the number of thyroid surgical procedures in almost all developed countries worldwide in the last few decades.

The most common symptom of UVFP is dysphonia, which may range from a mild change in voice quality to severe dysphonia with breathy voice and distinctive voice fatigue. Some patients also experience swallowing difficulties, especially in the first few months after the onset of paralysis. The third main symptom is dyspnea. Unlike bilateral paralysis, this is a rare symptom in UVFP that is reported by less than $3 \%$ of patients 5 .

In our series, all patients but one were surgically treated at least 6 months following the diagnosis of paralysis. In the meantime, patients underwent speech therapy and waited for potential spontaneous recovery of recurrent laryngeal nerve function. One patient required early augmentation only 2 months after thyroid surgery due to severe aspiration problems.

According to the duration of effect, augmentation materials may be categorized into temporary (short- 
lasting) and permanent (long-lasting). Traditionally, autologous fat has been included in the long-lasting group, but there is some disagreement in the literature regarding the accuracy of this classification ${ }^{15}$. According to the results of our study, both early postoperative and late postoperative results of voice assessment showed statistically significant improvement in all tested parameters (MPT, jitter, shimmer, NHR) in comparison with preoperative results. The reoperation rate was only $10.3 \%$ (8/78); thus, autologous fat augmentation in the paralyzed vocal fold provided a permanent solution to voice problems for the vast majority of patients in this series.

There are several techniques for harvesting and preparing autologous fat. The most commonly used are a surgical excision technique through a small skin incision and a lipoaspiration technique using 15 French canula connected to an aspirator under negative pressure. We surgically harvested autologous fat through a small skin incision in all patients based on several reports in the literature which suggested that surgically excised fat particles maintained greater volumes and viability compared with suction-aspirated fat ${ }^{2,3,16,17}$.

Autologous fat vocal fold augmentation appears to be a largely safe procedure, as very few laryngeal complications have been reported in the literature, the incidence of which ranges from $0.0 \%$ to $7.5 \% 0^{3,6,17-19}$. The overall complication rate in our series was $6.4 \%(5 / 78)$, and the laryngeal (injection site) complication rate was even lower at $3.8 \%(3 / 78)$. It is well-established that autologous fat vocal fold augmentation requires a certain amount of overcorrection to achieve a long-term result. However, the question remains whether it is possible to overexaggerate and augment too much fat, leaving the vocal fold in the permanent state of overcorrection. We have not experienced such a complication, but several literature reports have reported its occasional occurrence ${ }^{6,19}$. Furthermore, Sanderson reported that 3 cases of fat over-injection in their series of patients required revision surgery and excessive fat removal through lateral cordotomy ${ }^{6}$.

\section{Conclusion}

Autologous fat vocal fold augmentation is a highly useful and effective surgical technique with long-lasting results in the majority of patients suffering from UVFP, with an excellent safety profile and low compli- cation rate. However, the amount of resorption of injected fat is largely individual and sometimes unpredictable, requiring reoperation in some cases.

\section{References}

1. Mikaelian DO, Lowry LD, Sataloff RT. Lipoinjection for Unilateral Vocal Cord Paralysis. Laryngoscope. 1991;101:465-68. DOI: 10.1288/00005537-199105000-00003

2. Shaw GY, Szewczyk MA, Searle J, Woodroof J. Autologous fat injection into the vocal folds: Technical considerations and long-term follow-up. Laryngoscope. 1997;177-86. DOI: 10.1097/00005537-199702000-00008

3. Laccourreye O, Papon JF, Kania R, Crevier-Buchman L, Brasnu D, Hans S. Intracordal injection of autologous fat in patients with unilateral laryngeal nerve paralysis: Long-term results from the patient's perspective. Laryngoscope. 2003;113:54145. DOI: 10.1097/00005537-200303000-00027

4. Benninger MS, Hanick AL, Nowacki AS. Augmentation Autologous Adipose Injections in the Larynx. Ann Otol Rhinol Laryngol. 2016;125:25-30. DOI: 10.1177/0003489415595427

5. Granato F, Martelli F, Comini LV, Luparello P, Coscarelli S, Le $\mathrm{Seac} \mathrm{O}$ et al. The surgical treatment of unilateral vocal cord paralysis (UVCP): qualitative review analysis and meta-analysis study. Eur Arch Oto-Rhino-Laryngology. 2019;276:264959. DOI: $10.1007 / \mathrm{s} 00405-019-05587-2$

6. Sanderson JD, Simpson CB. Laryngeal complications after lipoinjection for vocal fold augmentation. Laryngoscope. 2009;119:1652-57. DOI: 10.1002/lary.20529

7. Prgomet D, Bilić M, Kovac L, Hutinec Z, Topić I. Locally invasive papillary thyroid cancer--our experience. Lijec Vjesn. 2012 Sep-Oct;134(9-10):266-70. Croatian

8. Walton C, Carding P, Flanagan K. Perspectives on voice treatment for unilateral vocal fold paralysis. Curr Opin Otolaryngol Head Neck Surg. 2018;26:157-61. DOI: 10.1097/MOO.00 00000000000450

9. Desuter G, Dedry M, Schaar B, van Lith-Bijl J, van Benthem PP, Sjögren E V. Voice outcome indicators for unilateral vocal fold paralysis surgery: a review of the literature. Eur Arch OtoRhino-Laryngology. 2018;275:459-68. DOI: 10.1007/s00405017-4844-9

10. Niechajev I, Sevcuk O. Long-term results of fat transplantation: Clinical and histologic studies. Plast Reconstr Surg. 1994;94: 496-506. DOI: 10.1097/00006534-199409000-00012

11. Kusić Z, Prgomet D. Karcinom štitne i doštitne žljezde. In: Prgomet D. Tumori glave i vrata. Zagreb: Medicinska naklada. 2019.p. 262-73. Croatian

12. Prgomet D, Janjanin S, Bilić M, Prstacić R, Kovac L, Rudes M, Katić V. A prospective observational study of 363 cases operated with three different harmonic scalpels. Eur Arch Otorhinolaryngol. 2009 ;266:1965-70. DOI: 10.1007/s00405-0090954-3.

13. Takano S, Nito T, Tamaruya N, Kimura M, Tayama N. Single institutional analysis of trends over 45 years in etiology of vocal 
fold paralysis. Auris Nasus Larynx. 2012;39:597-600. DOI: 10.1016/j.anl.2012.02.001

14. Cantarella G, Dejonckere P, Galli A, Ciabatta A, Gaffuri M, Pignataro L et al. A retrospective evaluation of the etiology of unilateral vocal fold paralysis over the last 25 years. Eur Arch Oto-Rhino-Laryngology. 2017;274:347-53. DOI: 10.1007/ s00405-016-4225-9

15. Hartl DM, Travagli JP, Leboulleux S, Baudin E, Brasnu DF, Schlumberger M. Clinical review: Current concepts in the management of unilateral recurrent laryngeal nerve paralysis after thyroid surgery. J Clin Endocrinol Metab. 2005;90:30848. doi: 10.1210/jc.2004-2533.

16. Bauer CA, Valentino J, Hoffman HT. Long-term result of vocal cord augmentation with autogenous fat. Ann Otol Rhinol
Laryngol. 1995;104:871-74. DOI: 10.1177/00034894951040 1109

17. Zaretsky LS, Shindo ML, Rice DH. Autologous fat injection for unilateral vocal fold paralysis. Ann Otol Rhinol Laryngol. 1996;105:602-06. DOI: 10.1177/000348949610500803

18. Hsiung MW, Pai L. Autogenous fat injection for glottic insufficiency: Analysis of 101 cases and correlation with patients' self-assessment. Acta Otolaryngol. 2006;126:191-96. DOI: 10.1080/00016480500339854

19. Anticaglia JR, Hawkshaw M, Sataloff RT. Too much fat, a rare complication of injection medialization laryngoplasty: A case report. J Voice. 2005;19:296-99. DOI: 10.1016/j.jvoice.2004. 02.004

\title{
AUGMENTACIJA AUTOLOGNOG MASNOG TKIVA U LIJEČENJU JEDNOSTRANE PARALIZE GLASNICE - 15-GODIŠNJE ISKUSTVO U JEDNOJ USTANOVI
}

\author{
R. Prstačić, J. Slipac, T. Živković Ivanović, I. Šimić, E.Babić i A. Đanić Hadžibegović
}

Augmentacija autolognog masnog tkiva u glasnice široko je rasprostranjen kirurški postupak koji se koristi u liječenju fonatorne glotidne insuficijencije kod pacijenata s jednostranom paralizom glasnice. Međutim, u literaturi postoje određene dvojbe oko dugoročnih rezultata ove tehnike. U Klinici za bolesti uha, nosa i grla i kirurgiju glave i vrata KBC-a Zagreb ovom se tehnikom služimo već više od 15 godina te smo proveli retrospektivnu analizu povijesti bolesti bolesnika s jednostranom paralizom glasnice od lipnja 2005. do studenog 2019. Sveukupno je 78 bolesnika ispunjavalo kriterije za ulazak u studiju. Kod svih bolesnika učinjena je barem jedna predoperativna i dvije postoperativne objektivne analize glasa, jedna rana (unutar 3 mjeseca od operacije) i jedna kasna (najmanje 1 godinu nakon operacije). Svi testirani parametri analize glasa (maksimalno vrijeme fonacije (MPT), jitter, shimmer, omjer šuma i harmonika (NHR)) značajno su poboljšani nakon operacije i rano postoperativno i kasno postoperativno $(\mathrm{p}<0,001)$. Stopa reoperacija u ovom uzorku bila je samo $10,3 \%(8 / 78)$, tako da je većina pacijenata obuhvaćena ovim istraživanjem imala dugoročno poboljšanje glasa nakon ovog kirurškog zahvata.

Prema rezultatima našeg istraživanja, augmentacija autolognog masnog tkiva u glasnice vrlo je korisna i učinkovita kirurška tehnika s dugotrajnim rezultatima kod većine pacijenata s jednostranom paralizom glasnice.

Ključne riječi: autologno masno tkivo, augmentacija, paraliza glasnica 